\title{
Maringa-Lopori-Wamba Landscape
}

Jules Mayifilua, Deo Mbula, Jean-Claude Muliele and Innocent Ombeni

\section{Introduction}

The Maringa-Lopori-Wamba (MLW) landscape is bordered by the Maringa and Lopori rivers, the administrative and territorial entities of Bongandanga, Basankusu, Befale and Djolu in the districts of Equateur, Mongala and Tshuapa in the Equateur Province.

The landscape covers $74544 \mathrm{~km}^{2}$ of tropical forest and includes some inhabited areas along the rivers. It is very isolated and remote mainly because of the degradation of the road infrastructure which has been occurring since the 1980s and 1990s.

The whole landscape is located within the Congo region. The Maringa and Lopori rivers originate the southeast of MLW and flow through the the landscape with their tributaries, the Lomako, Yokokala and Bolombo rivers. The Maringa and Lopori rivers meet in the northwest near Basankusu to form the Lulonga River.

The climate in the region is hot and equatorial, with an average annual rainfall of $2000 \mathrm{~mm}$ and barely distinguishable seasons. The most humid period runs from August to October and the dry season (January-February) generally lasts less than two months.

\section{Population}

The population density of the MLW landscape is estimated at 8 inhabitants $/ \mathrm{km}^{2}$. It is mainly concentrated along the main roads and in Basankusu, Befale, Bongandanga, Mompono, Djolu and Lingomo.

The landscape is fully encased in Mongo land (Mongo and Mongando). For decades, Ngombe, who are considered great hunters, have migrated from north to south. In the central north-east there are small numbers of Pygmies. At the centre of the landscape, between the Lomako and Yokokala rivers, a few thousand Kitiwalists (a religious sect) have withdrawn to the forest since the 1960s.

The populations settled along the main roads mostly practice agriculture. Because of the decline of slash-andburn agriculture and the difficulties of accessing markets,

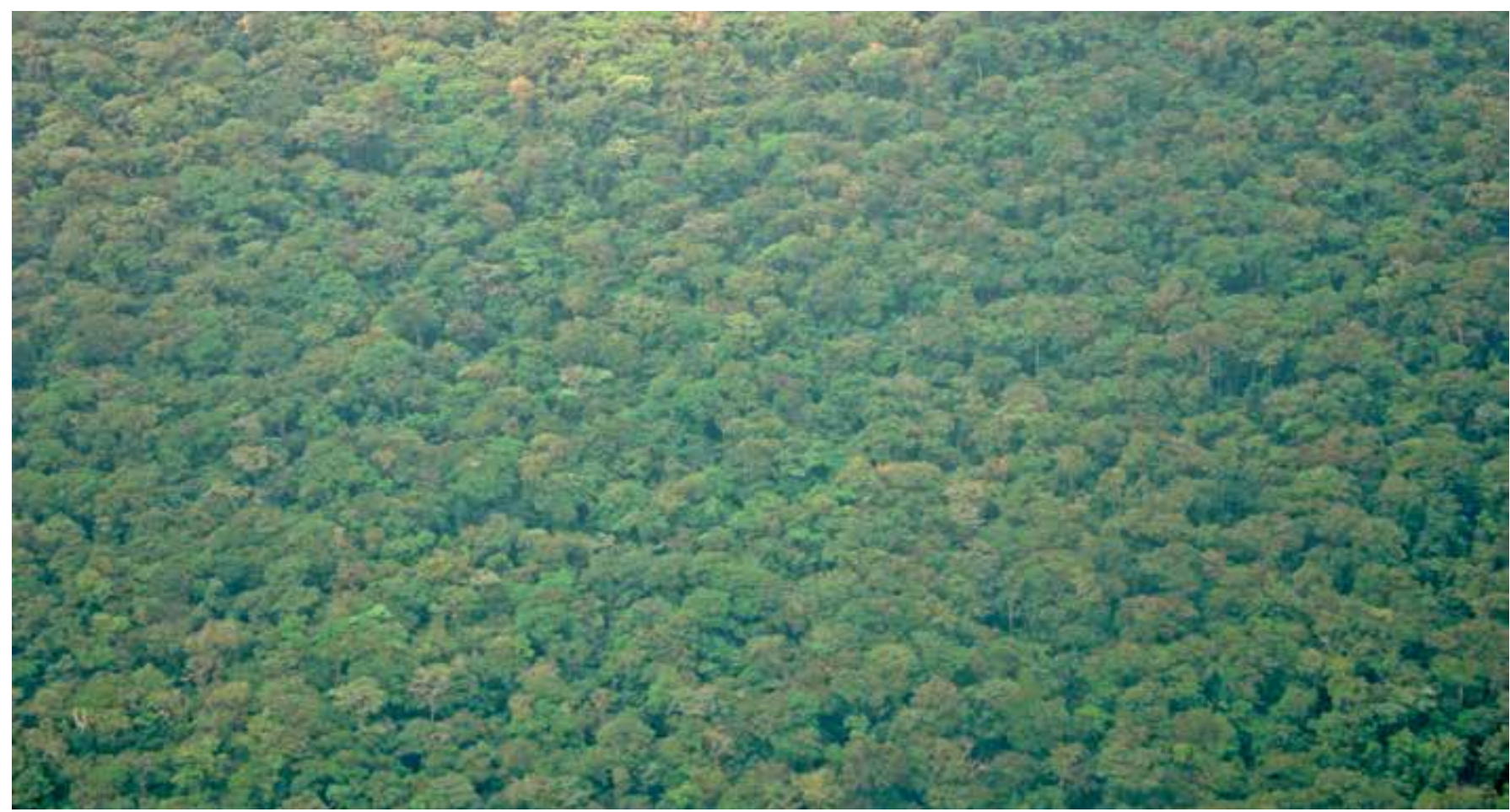


farmers have turned to forests for natural resources such as bush meat, fish and non-timber forest products. Hunting is practiced throughout the landscape.

\section{Vegetation}

Dense humid forests constitute the largest part of the landscape (see Figure 1). Dry land forest makes up 67 percent of the landscape, while floodplain and/or swampy forests along the rivers cover 25 percent. Dry lands forests are made up of ombrophilous semi-evergreen forests with Scorodophloeus zenkeri, and ombrophilous evergreen forests with monodominance of Gilbertiodendron dewevrei or Brachystegia laurentii. Edaphic formations are made up of riparian forests of Uapaca heudelotii, floodplain forests of Oubanguia africana and swampy forests of Entandrophragma palustre or Coelocaryon botryoides.

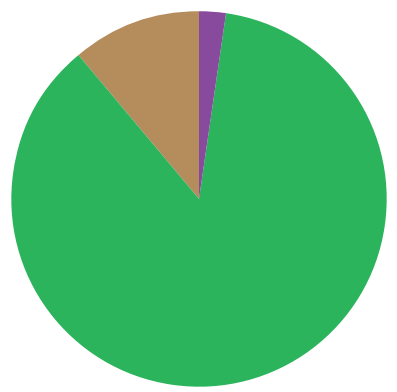

Inundatable forest (2.3\%)

Dense forest 0-1000 m (86.6\%)

Forest-cultivation mosaic (11.1\%)

Figure 1. Different types of vegetation found in the landcape Source: Joint Research Centre (JRC - European Commission) 2006
Degraded forests and agricultural areas make up the remaining 7 percent of vegetation cover. Forest plantations cover less than 1 percent. They are found along road sides and near homes along the Maringa, Lopori and Bolombo rivers, and close to the roads linking Djolu, Lingomo, Mompono and Befori.

\section{Deforestation}

The two main causes of deforestation are slash-and-burn agriculture, which transforms primary forests into agricultural lands and later into secondary forests, and timber logging, which changes forest density and specific composition. Deforestation was estimated at 0.33 percent during 20002005 (Presentation of the MLW Landscape, in Carlos WASEIGE and Didier DENVERS (Ed.), Les forêts du Bassin du Congo : Etat des forêts 2008, Luxembourg, Office for Official Publications of the European communities 2009).

\section{Biodiversity}

The ecological value of the MLW landscape is globally significant. The landscape includes a substantial portion of the Congo Basin forest ecosystem, which is home to a variety of essential species, such as Bonobo, great pangolins, golden cats, forest elephants, Congo peacocks and many primates, amphibians and rare reptiles. The landscape also harbours a huge variety of birds and fish.

\section{Parks and Reserves}

- Lomako-Yokokala Wildlife Reserve

- Koko-Lopori Wildlife Reserve

- Luo Scientific Reserve

- $\quad$ lyondji Scientific Reserve

- Bonobo (Ekolo ya bonobo) Reserve

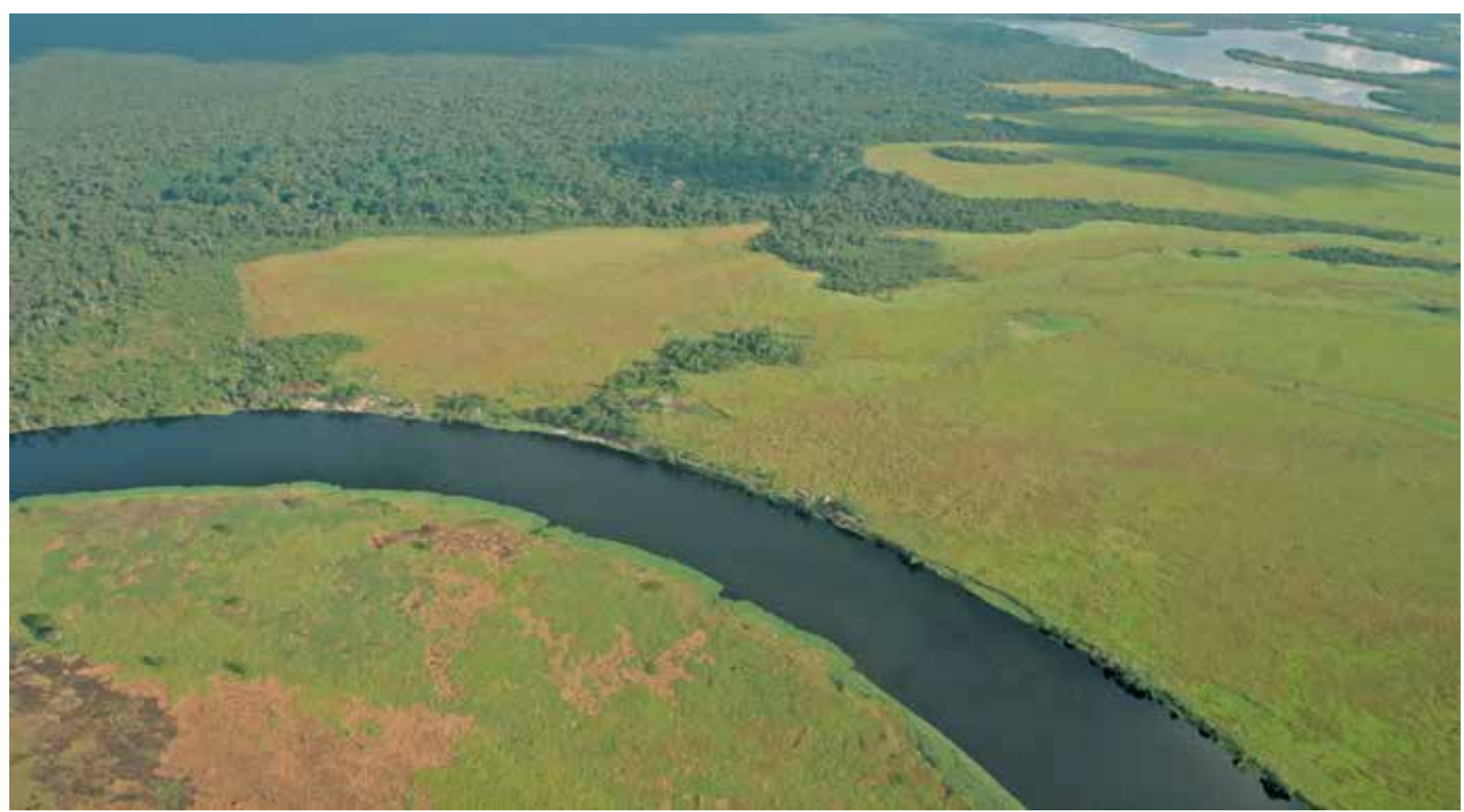

Panoramic view of Congo forest

Photo by Craig R. Sholley/AWF 


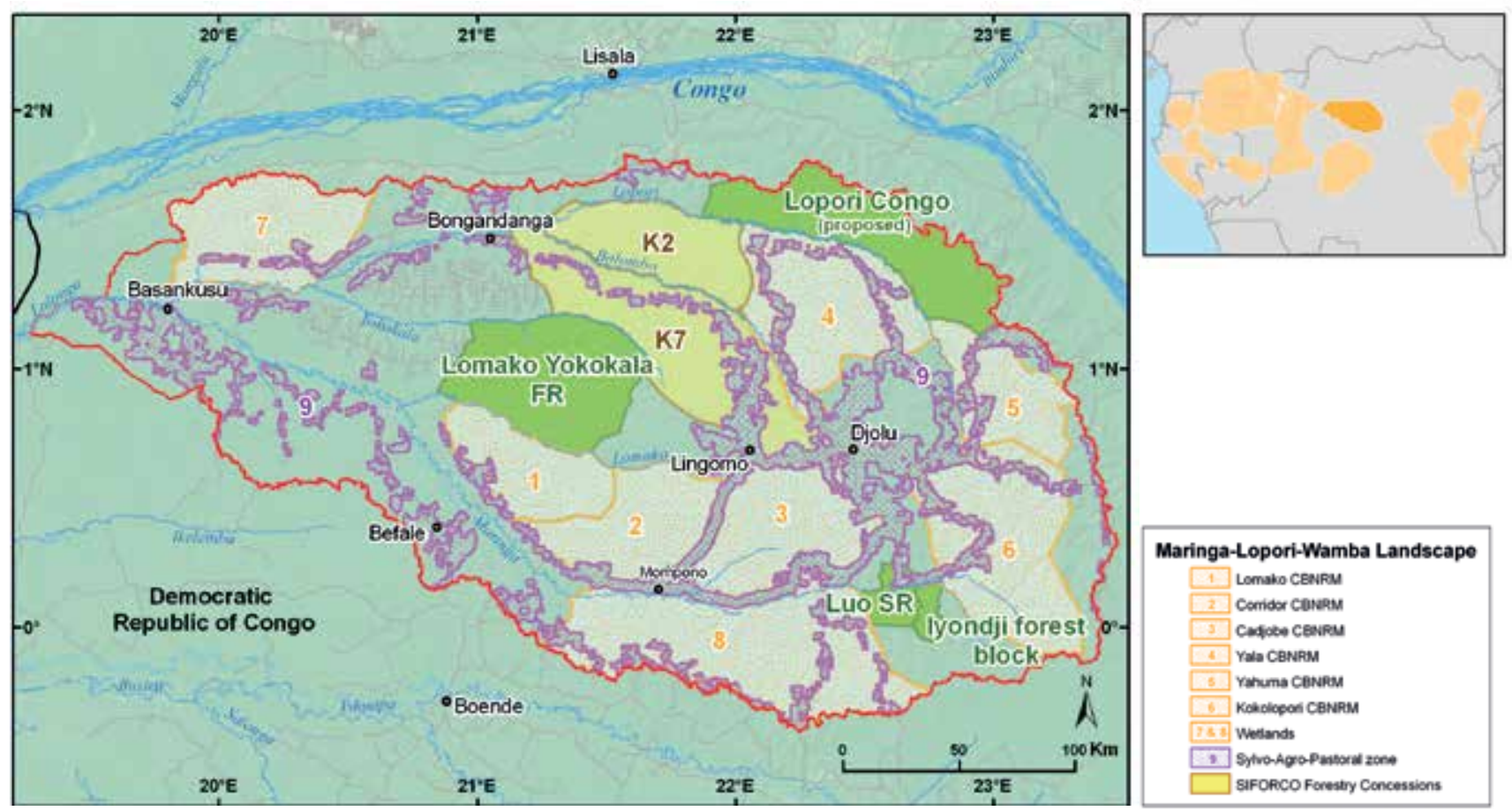

Figure 2. Land use planning in the MLW landscape

Source: AWF, UDM-CARPE, OSFAC, FORAF, IUCN, Tom Patterson, US National Park Service 2009

\section{Threats}

The main threats to biodiversity in the MLW landscape are linked to the livelihoods of local populations, who rely on subsistence agriculture and non-sustainable hunting for bush meat. Threats also include non-sustainable commercial hunting and traditional and industrial timber harvesting.

\section{Land use}

Partners at the national and local levels have carried out research into land uses, and considerable progress has been made. A draft land use development plan, covering approximately 70 percent of the landscape, has been produced from a biological inventory, socioeconomic studies, satellite images and consultations with local, national and international stakeholders.

To date, four types of land use or macro-zones have been identified:

- $\quad$ protected areas (2)

- $\quad$ natural resource extraction areas (3)

- community management natural resources areas (8)

- $\quad$ agroforestry-pasture areas.

\section{Institutional partners}

The main institutional partners managing the MLW landscape include:

- Congolese Wildlife Authority ( Institut Congolais pour la Conservation de la Nature/ICCN)

- $\quad$ African Wildlife Foundation (AWF)

- University of Maryland - Central African Regional Program for Environment (UMD-CARPE)

- Tom Patterson

- $\quad$ Satellite observation of the Central African Forests (OSFAC)
- African Forests (FORAF)

- International Union for Conservation of Nature (IUCN)

- US National Park Service

- $\quad$ Friends of the Bonobo in Congo (Les Amis des Bonobos du Congo/ABC).

\section{Opportunities, adaptation and REDD+}

Forests play a crucial role in climate change mitigation and adaptation systems, because of their capacity to absorb and store substantial quantities of carbon dioxide. The AWF (African Wildlife Foundation), together with SOIL (Sustainable Opportunities for Improving Livelihoods), has implemented a programme on REDD in the MLW landscape. The main objective of this programme is to develop a database for the monitoring, reporting and verification of greenhouse gas emissions and for carbon stocks.

Two main activities have been identified in line with the National REDD Strategy for the Democratic Republic of the Congo, which is under review. They are:

- Reducing greenhouse gases resulting from deforestation and degradation, and reforestation through the conversion of forests into a Rural Development Area as already established in the area plan (macro-areas and micro-areas).

- Carbon sequestration through the development of agroforestry systems.

It is important to mention that other opportunities are being investigated under the REDD+, taking into consideration the wellbeing of local communities. SOIL has also decided to design a summary document on REDD, in order to facilitate monitoring of the process in the landscape. 


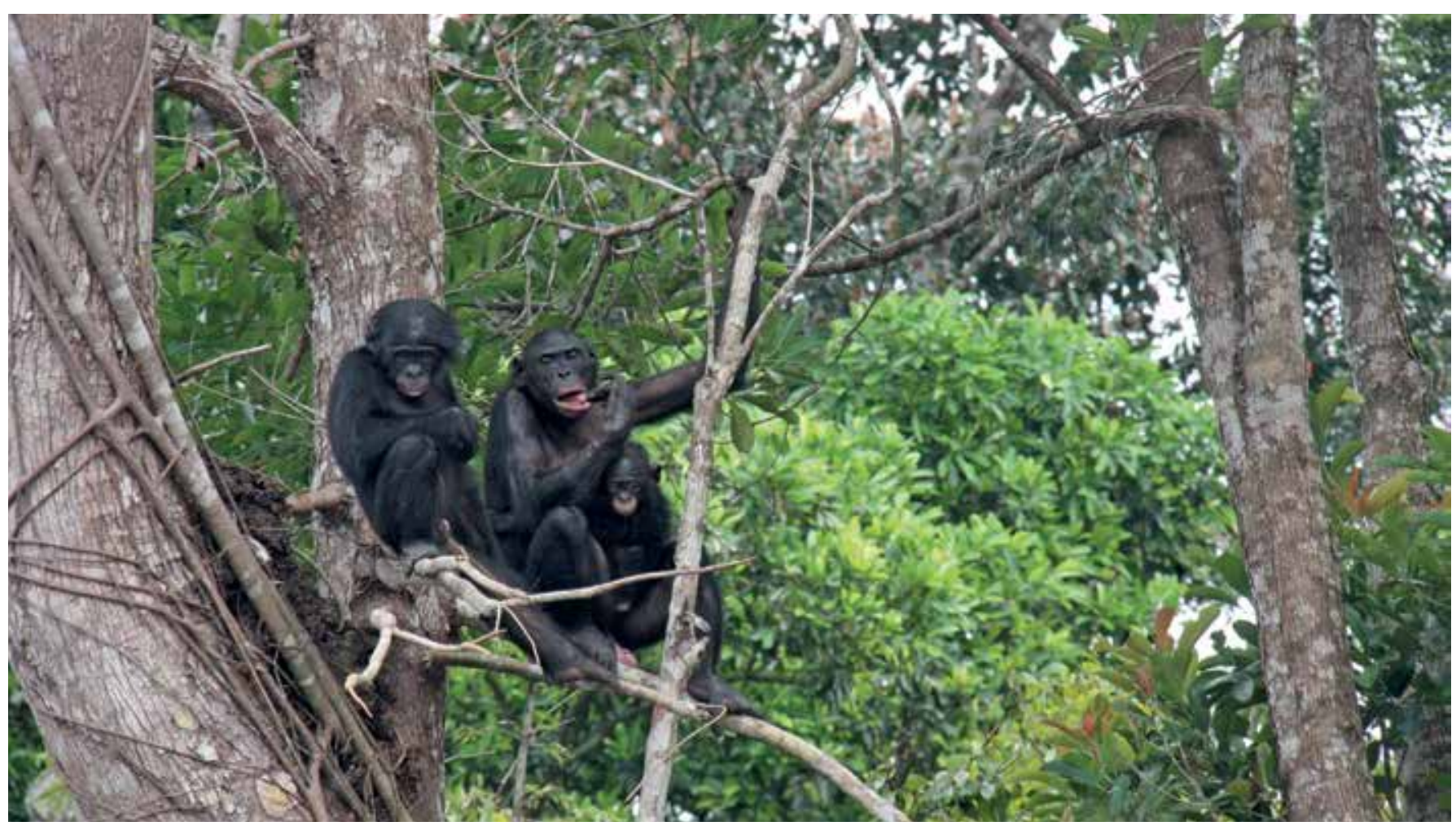

Bonobos in MLW landscape

Photo by Brenda Brainch/AWF

\section{Challenges and constraints}

- $\quad$ Reducing deforestation rates

- Involving communities in the sustainable management of wildlife resources
- High poverty rates

- Lack of conservation action ownership by communities

- Difficulty in accessing the landscape.

COBAM is implemented by CIFOR under the African Development Bank (AfDB) grant to the Economic Community of Central African States (ECCAS) for financing the Congo Basin Ecosystems Conservation Support Program (PACEBCo).

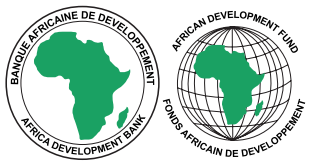

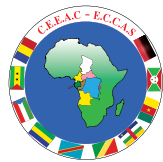
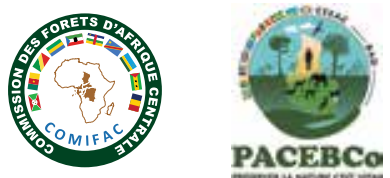

cifor.org/cobam

blog.cifor.org

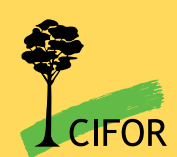

CIFOR advances human wellbeing, environmental conservation and equity by conducting research to inform policies and practices that affect forests in developing countries. CIFOR is a CGIAR Consortium Research Center. 